\title{
PENGEMBANGAN BAHAN AJAR BERBASIS ETNOMATEMATIKA KESENIAN REBANA UNTUK MENINGKATKAN LITERASI MATEMATIS SISWA SMP
}

\author{
Aris Dwi Cahyono \\ Program Studi Pendidikan Matematika, FMIPA, Universitas Negeri Surabaya \\ e-mail: ariscahyono16030174023@mhs.unesa.ac.id \\ Mega Teguh Budiarto \\ Program Studi Pendidikan Matematika, FMIPA, Universitas Negeri Surabaya \\ e-mail: megatbudiarto@unesa.ac.id
}

\begin{abstract}
Abstrak
Perkembangan zaman yang semakin pesat mengakibatkan berkurangnya kesadaran terhadap pelestarian kebudayaan lokal oleh generasi muda melalui sarana pendidikan. Saat ini budaya lokal mulai dilupakan, banyak yang lebih tertarik pada budaya asing. Hal ini dapat membuat bangsa kita kehilangan identitas budaya. Selain itu, kemampuan literasi matematis siswa di Indonesa sangatlah rendah. Hasil studi PISA tahun 2018 yang menyatakan bahwa negara Indonesia mengalami penurunan peringkat dan konsisten berada di klasemen bawah dengan perolehan skor dibawah rata-rata. Untuk mengatasi hal tersebut, alternatif yang dapat dilakukan adalah melalui sarana pendidikan salah satunya dengan menerapkan etnomatematika yang mendukung literasi matematis ke dalam pembelajaran. Tujuan penelitian ini adalah untuk menghasilkan LKS berbasis etnomatematika kesenian rebana sebagai bahan ajar untuk mendukung literasi matematis siswa dan untuk mengetahui nilai validitas dan reliabilitas bahan ajar yang dikembangkan. Penelitian ini menggunakan model pengembangan ADDIE. Hasil penelitian menunjukkan bahwa LKS dinyatakan valid dengan skor validasi 3,25, RPP dinyatakan valid dengan skor validasi 3,43, THB dinyatakan valid dengan skor validasi 3,32 dan reliabilitas THB 0,62, dan instrumen angket respon siswa dinyatakan valid dengan skor validasi 3,57. Integrasi etnomatematika kesenian rebana dalam LKS pada materi bangun ruang sisi lengkung menyajikan informasi tentang sejarah, kegunaaan, dan jenis-jenis pada kesenian rebana untuk mendukung literasi matematis dapat membuat pembelajaran lebih bermakna, karena selain belajar konsep dalam waktu yang sama siswa juga mempelajari kearifan lokal. Diharapkan siswa mampu lebih memahami, memaknai, menghargai, dan menyadari pentingnya nilai budaya dalam menjalankan aktivitas dalam kehidupan seharihari.
\end{abstract}

Kata Kunci: etnomatematika, kesenian rebana, ADDIE

\section{Abstract}

The current development which is growing rapidly makes a lack awareness of local culture conservation by young generation through educational facilities. Now days, local culture was begin forgotten, many people more interested with foreign culture. This can make our nation lose its cultural identity. Besides that, students' mathematical literacy ability in Indonesia is very low. The results of PISA study in 2018 stated that the Indonesia had decreased in rank and were consistently at the bottom of the table with below average scores. To overcome this case, an alternative that can be done is through educational facility which is by applying ethnomatematics that supports mathematical literacy in a learning process. The purpose of this research is to produce ethnomatemics based worksheet tambourine as a teaching material to support students' mathematical literacy and to find out the value of validity and reliability of teaching materials developed. This research uses the ADDIE development model. The results showed that the worksheet was valid with a validation score of 3.25 , the RPP was declared valid with a validation score of 3.43 , THB was declared valid with a validation score of 3.32 and the reliability of the THB was 0.62 , and the student questionnaire response was declared valid with a validation score of 3.57. The integration of tambourine etnomathematics in curved side space worksheet present about the history, function, and type of tambourine for supporting mathematics literacy so that learning activities can be meaningful, because through this worksheet student not only learn about the concept but also learn about local wisdom. It is expected that students will be able to better understand, interpret, appreciate, and realize the importance of cultural values in carrying out activities in daily life.

Keywords: ethnomematics, tambourine arts, ADDIE 


\section{PENDAHULUAN}

Budaya merupakan suatu hal yang tidak dapat dihindari dalam aktivitas sehari-hari. Budaya adalah pola perilaku manusia dan produk yang dihasilkannya tergantung pada kemampuan seseorang untuk belajar dan menyampaikan pengetahuannya kepada generasi berikutnya dengan beragam alat, bahasa dan pola nalar (Wahyuni, 2013; Budiarto, 2016). Salah satu contoh budaya adalah kesenian rebana. Kesenian rebana merupakan kesenian bernuansa islami yang memiliki nilai estetika. Dilihat dari teknik memainkan alat musik rebana yang disesuaikan dengan irama lagu, syair, atau jenis shalawat yang dikumandangkan. Dalam kesenian rebana sendiri terdapat beberapa ketukan atau rumus, dan ada juga yang mengatakannya dengan kunci yaitu kunci satu dan dua, ada juga yang mengatakannya dengan kunci lanangan dan wadonan. Perkembangan zaman yang semakin pesat mengakibatkan adanya perubahan mulai dari nilai, norma, dan tradisi adat istiadat (Putri 2017; Ramadhani 2019). Kurangnya kesadaran generasi muda dalam melestarikan budaya berpengaruh pada selera musik termasuk kesenian rebana (Ramadhani, 2019). Nilai budaya yang merupakan landasan karakter bangsa sangatlah penting untuk ditanamkan pada setiap orang, untuk itu perlu ditanamkan sejak dini melalui pembelajaran, agar setiap orang mampu lebih memahami, memaknai, menghargai, dan menyadari pentingnya nilai budaya dalam menjalankan setiap aktivitas dalam kehidupan sehari-hari (Wahyuni, 2013).

Pembelajaran sebagai sarana untuk memberikan ilmu pengetahuan dan pelestarian kebudayaan yang dilakukan oleh guru di Indonesia masih banyak yang berpusat pada guru. Pemahaman yang masih kurang memadai dan paradigma pembelajaran yang kurang sesuai dengan tindakan yang seharusnya dilakukan mengakibatkan pembelajaran masih berpusat pada guru (Sani, 2013). Dalam dunia pendidikan, proses pembelajaran tak lepas dari perangkat pembelajaran atau kurikulum. Kurikulum berkembang dari masa ke masa sampai saat ini yang masih berlaku adalah kurikulum 2013 Perubahan yang mendasar terjadi khususnya pada standart proses pembelajaran semenjak diberlakukannya kurikulum 2013 oleh pemerintah untuk menyempurnakan kurikulum sebelumnya, yaitu KTSP 2006 (Wiyono, 2013). Salah satu perubahannya, kurikulum menuntut dalam penyusunan bahan ajar yang kreatif, inovatif, menarik, dan kontekstual.

Bahan ajar dapat membantu pendidik dalam pelaksanaan pembelajaran dengan bentuk konsep, prinsip, definisi, konteks, data, proses, nilai dan keterampilan (Majid, 2011; Sumantri, 2015). Sampai sekarang pengembangan bahan ajar berbasis budaya tidaklah banyak, padahal pembelajaran kontekstual sangat ditekankan (Nelawati dkk, 2018). Pembelajaran kontekstual dapat dilakukan melalui pembelajaran berbasis kebudayaan yang memungkinkan guru dan siswa berpartisipasi aktif sehingga pembelajaran dapat memperoleh hasil belajar yang optimal (Pannen, 2010). Implementasi pembelajaran berbasis budaya dapat dilakukan pada bidang Matematika, Matematika dan budaya merupakan dua hal yang berkaitan erat (Muhtadi, 2017; Risdiyanti, 2017; Ditasona, 2018).

Jembatan antara budaya dan matematika adalah etnomatematika. Etnomatematika dapat dideskripsikan sebagai aturan khusus yang digunakan oleh masyarakat atau golongan tertentu untuk menggunakan ide dan konsep secara matematika dalam kehidupan sehari-hari (D’Ambrosio, 1985; Rachmawati, 2012; Risdiyanti, 2017; Ditasona, 2018; Budiarto, 2019). Etnomatematika memudahkan siswa dalam mengaitkan matematika dan budaya, sehingga pemahaman siswa terhadap matematika menjadi lebih akurat dan pembelajaran dapat bermakna karena diselaraskan dengan budaya dan kehidupan bermasyarakat (Wahyuni, 2013; Ditasona, 2018; Budiarto, 2019). Ekspansi penggunaan etnomatematika yang selaras dengan keanekaragaman budaya dan praktik matematika dalam keseharian siswa dapat membawa matematika lebih dekat dengan lingkungan siswa (Francois, 2012).

Penerapan matematika dalam kehidupan sehari-hari juga sering dikaitkan dengan literasi matematis. Pemanfaatan literasi matematis lebih kepada penguasaan problem solving yang memerlukan penalaran serta harus mampu menggunakan logika dalam setiap pengambilan keputusan, tidak sekedar menggunakan pemahaman arithmetic (Linuhung dalam Kusumah, 2011: 3). Pada hari Selasa, 3 Desember 2019, hasil studi Programme for International Student Assessment tahun 2018 telah dirilis. Berdasarkan hasil studi tersebut, Programme for International Student Assessment menilai 600.000 anak berusia 15 tahun dari 79 negara setiap tiga tahun sekali dan Indonesia mengalami penurunan peringkat jika dibandingkan dengan studi sebelumnya (Tohir, 2019). Aspek yang dibandingkan pada studi ini antara lain kemampuan matematika, membaca, dan kinerja sains dari anak.dari tiap studi yang dilakukan stiap tiga tahun sekali, indonesia selalu saja konsisten berada di peringkat klasemen bawah dengan perolehan skor yang selalu kurang dari rata-rata, hal ini menunjukkan kemampuan literasi matematis di Indonesia sangatlah rendah. Sehingga tujuan dari penelitian ini adalah untuk menghasilkan bahan ajar berbasis etnomatematika kesenian rebana yang digunakan sebagai sumber belajar untuk mendukung literasi matematis siswa.

Permendiknas No. 22 Tahun 2006 tentang Standar Isi Mata Pelajaran Matematika lingkup pendidikan dasar menyebutkan bahwa mata pelajaran matematika bertujuan agar siswa memiliki lima kemampuan kunci sebagai 
berikut: (1) memahami, menjelaskan, dan mengaplikasikan konsep matematika (2) menggunakan penalaran (3) memecahkan masalah (4) mengkomunikasikan gagasan (5) memiliki sikap menghargai kegunaan matematika dalam kehidupan. Tujuan tersebut sejalan dengan gagasan mengenai literasi matematis. Dalam upaya mendukung literasi matematis dapat dilakukan dengan inovasi pada pembelajaran matematika yaitu dengan menerapkan etnomatematika (Prayitno, 2016; Fajriyah, 2018). Pembelajaran matematika berbasis budaya atau yang disebut dengan etnomatematika merupakan salah satu cara yang dipersepsikan dapat membuat pembelajaran lebih bermakna dan kontekstual yang berkaitan erat dengan komunitas budaya. Selain itu, pembelajaran matematika berbasis budaya akan menjadi alternatif pembelajaran yang menarik, menyenangkan, dan inovatif karena memungkinkan terjadinya pemaknaan secara kontekstual berdasarkan pada pengalaman siswa sebagai anggota suatu masyarakat budaya sehingga diharapkan dapat turut serta mendukung gerakan literasi. Hasil penelitian Prayitno (2016) menyebutkan bahwa terdapat pengaruh pembelajaran etnomatematika Sunda terhadap kemampuan literasi matematis siswa sekolah dasar. Dari penelitian tersebut, etnomatematika berperan dalam mendukung literasi, khususnya literasi matematis. Penerapan etnomatematika dalam pembelajaran matematika dapat membantu siswa dalam mengkonstruksi konsep sebagai bagian dari literasi matematis. Selain itu, etnomatematika menyediakan lingkungan pembelajaran yang menciptakan motivasi yang baik dan lebih menyenangkan sehingga siswa memiliki minat yang besar dalam mengikuti pembelajaran matematika serta diharapkan dapat berpengaruh positif terhadap kemampuan matematika mereka, khususnya kemampuan literasi matematis.

Bahan ajar dapat membantu pendidik dalam pelaksanaan pembelajaran dengan bentuk konsep, prinsip, definisi, konteks, data, proses, nilai dan keterampilan (Majid, 2011; Sumantri, 2015). Menurut Prastowo (2013), bahan ajar dapat dikelompokkan menjadi empat jenis berdasarkan bentuk, yaitu bahan ajar cetak, bahan ajar dengar, bahan ajar pandang dengar, dan bahan ajar interaktif. Berdasarkan modul yang dikeluarkan oleh Direktorat Jenderal Peningkatan Mutu Pendidik Dan Tenaga Kependidikan Depdiknas 2008, bahan ajar memiliki beberapa karakteristik, yaitu self instructional, self contained, stand alone, adaptive, dan user friendly (Widodo \& Jasmadi, 2010).

Budaya adalah pola perilaku manusia dan produk yang dihasilkannya tergantung pada kemampuan seseorang untuk belajar dan menyampaikan pengetahuannya kepada generasi berikutnya dengan beragam alat, bahasa dan pola nalar (Wahyuni, 2013; Budiarto, 2016). Koentjaraningrat (1985) mengemukakan bentuk dari budaya terdapat tiga macam, yaitu (1) sebagai gagasan, nilai, peraturan,dan sebagainya; (2) sebagai suatu aktivitas atau tindakan yang memiliki pola dari masyarakat; dan (3) sebagai benda hasil karya tangan manusia. Menurut Sarinah (2016), budaya memiliki sifat universal, yaitu (1) milik bersama; (2) berhubungan dengan situasi masyarakat; (3) berfungsi untuk membantu manusia; (4) diwariskan melalui proses belajar.

Etnomatematika dapat dideskripsikan sebagai aturan khusus yang digunakan oleh masyarakat atau golongan tertentu untuk menggunakan ide dan konsep secara matematika dalam kehidupan sehari-hari (D'Ambrosio, 1985; Rachmawati, 2012; Risdiyanti, 2017; Ditasona, 2018; Budiarto, 2019). Etnomatematika memiliki makna konseptual sehingga menerapkan konsep matematika didalamnya. Menurut Sirate (2011), aktivitas etnomatematika yang diterapkan dalam masyarakat, yaitu (1) Membilang (2) Mengukur (3) Menentukan Lokasi (4) Membuat Rancang Bangun (5) Bermain (6) Menjelaskan. Hasil Penelitian Purwiyantini, Yeni, dkk (2016) menunjukkan bahwa semakin besar diameter rebana didapatkan semakin menurunnya frekuensi rebana secara teratur. Demikian juga untuk intensitas bunyi rebana, keteraturan penurunan intensitas juga dipengaruhi oleh ukuran diameter rebana yang semakin besar. Di sisi lain, Putri (2017) mengatakan bahwa dalam proses pembuatan alat musik rebana juga menggunakan konsep dasar geometri.

Beberapa peneliti telah membuat bahan ajar berbasis etnomatematika yang dapat digunakan dalam pembelajaran. Jarnawi A. D dan Revina P (2018) mengembangkan bahan ajar berbasis etnomatematika yang berupa lembar kerja siswa pada topik himpunan. Lebih lanjut Ayuningtyas dan Setiana (2019) menyatakan bahwa pengembangan bahan ajar berbasis etnomatematika Kraton Yogyakarta dapat membantu siswa memahami konsep yg dipelajari karena menggunakan benda-benda konkret yang ada disekitarnya. Pada penelitian kali ini sedikit berbeda dengan penelitian yang ada sebelumnya. Penelitian sebelumnya hanya mengembangkan bahan ajar berbasis etnomatematika, sedangkan penelitian ini mengembangkan bahan ajar dengan mengaitkan etnomatematika dan literasi matematis.

Literasi matematis merupakan sebuah proses (merumuskan, menerapkan, dan menginterpretasikan) untuk menyelesaikan masalah matematika dalam kehidupan sehari-hari (Steen, 2007; Ojose, 2011; OECD, 2017; Abdussakir, 2018). Menurut Abdussakir (2018), terdapat delapan kompetensi literasi matematis, yaitu (1) berpikir matematis (2) mengajukan dan memecahkan masalah matematika (3) pemodelan matematika (4) penalaran matematika (5) representasi entitas matematika (6) menangani simbol matematika dan formalism (7) 
berkomunikasi dalam, dengan, dan tentang matematika (8) memanfaatkan alat bantu dan peralatan (termasuk teknologi informasi). Untuk mencapai kompetensikompetensi tersebut, pembelajaran tidak hanya aspek rutin saja, perlu diarahkan ke aspek non rutin juga. Matematika tidak boleh sekedar dilihat sebagai komputasi dan manipulasi simbol saja. Siswa juga harus diajak untuk lebih mendalami makna dan pemahaman matematis. Guru harus memberikan kesempatan kepada siswa untuk bekerja dalam pemecahan masalah yang berkaitan dengan kehidupan sehari-hari dan mencari keterkaitan beserta maknanya.

\section{METODE}

Penelitian ini termasuk penelitian pengembangan dengan subjek penelitian siswa SMP kelas IX karena pada umumnya siswa kelas IX berusia 15 tahun sesuai dengan kriteria peserta tes PISA tahun 2018 sehingga melalui penelitian ini diharapkan dapat melatih kemampuan literasi matematis siswa. Menurut Sugiyono (2017) penelitian pengembangan merupakan proses yang digunakan untuk memvalidasi dan mengembangkan produk. Penelitian ini mengembangkan bahan ajar LKS yang dilengkapi dengan RPP dan THB menggunakan model ADDIE yang dikembangkan oleh Dick \& Carry meliputi Analysis, Design, Development, Implementation, and Evaluation (Sugiyono, 2017). Berikut merupakan bagan model pengembangan ADDIE yang diadaptasi dari Zulfikri (2018).

Bagan 1. Model pengembangan ADDIE

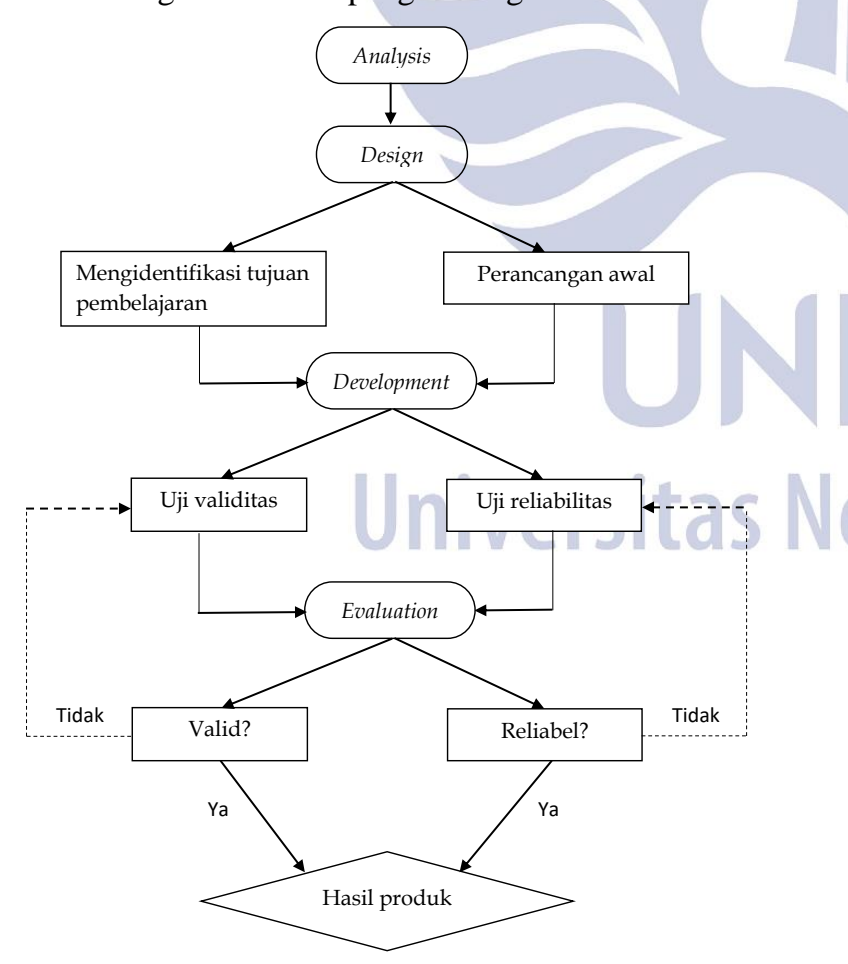

Tahap analysis pada penelitian ini yaitu langkah untuk mendeskripsikan hal hal yang akan dibahas sebagai dasar dari langkah lainnya. Hal-hal yang dianalisis meliputi analisis kebutuhan dan analisis karakteristik. Tahap design pada penelitian ini yaitu dilakukan pemilihan bentuk bahan ajar dan membuat design bahan ajar berbasis etnomatematika kesenian rebana yang disesuaikan dari tahap analysis. Tahap development pada penelitian ini yaitu mengembangkan bahan ajar berdasarkan konsep yang sudah didesain dan divalidasi oleh tiga validator dengan rincian dua dosen dan satu guru matematika. Tahap implementation pada penelitian ini yaitu dilakukan uji coba pembelajaran menggunakan bahan ajar berbasis etnomatematika kesenian rebana yang telah divalidasi oleh validator. Pada tahap ini belum bisa dilaksanakan karena situasi dan kondisi pada saat ini terkait wabah virus yang melanda negeri ini mengakibatkan sekolah-sekolah diliburkan sehingga aktivitas pembelajaran dibatasi dan tidak memungkinkan untuk uji coba. Tahap evaluation pada penelitian ini yaitu evaluasi bahan ajar dan instrumen yang divalidasi pada tahap development dengan merevisi berdasarkan penilaian dan masukan dari ketiga validator hingga dinyatakan valid.

Data yang dihasilkan berupa kuantitatif dan kualitatif. Data kuantitatif diperoleh dari hasil penilaian validasi LKS, RPP, THB, dan instrumen angket respon siswa. Sedangkan data kualitatif diperoleh dari masukan dari ketiga validator dan deskripsi hasil penilaian validasi instrumen. Instrumen pengumpulan data dalam penelitian ini yaitu lembar validasi LKS, lembar validasi RPP, lembar validasi THB, lembar validasi angket respon siswa, lembar observasi, lembar kepraktisan, angket respon siswa, dan tes hasil belajar.

Tabel 1. Kriteria Validitas

\begin{tabular}{|c|c|}
\hline Nilai & Kriteria \\
\hline $4=V a$ & Sangat valid \\
\hline $3 \leq V a<4$ & Valid \\
\hline $2 \leq V a<3$ & Kurang valid \\
\hline $1 \leq V a<2$ & Tidak valid \\
\hline
\end{tabular}

Ket: $V a=$ rata-rata total validitas

Langkah atau tahapan yang dilakukan dalam menganalisis antara lain:

(1) Merekap semua pernyataan atau pertanyaan ke tabel 2.

Tabel 2. Rekapitulasi Hasil Validitas

\begin{tabular}{|l|l|l|l|l|l|l|}
\hline \multirow{2}{*}{ Aspek } & \multirow{2}{*}{ Kriteria } & \multicolumn{3}{|c|}{ Validator } & \multirow{2}{*}{$K i$} & \multirow{2}{*}{$A i$} \\
\hline & & & & & & \\
\hline & & & & & & \\
\hline & & & & & & \\
\hline
\end{tabular}

(2) Menghitung rata-rata dari tiap kriteria oleh seluruh validator

$$
K i=\frac{\sum_{j=1}^{n} V j i}{n}
$$

Keterangan 
$K i=$ rata-rata kriteria ke- $i$

$V j i=$ skor penilaian validator ke- $j$ untuk $K i$

$n$ = banyaknya validator

Diadaptasi dari Khabibah (2006)

(3) Menghitung rata-rata dari tiap aspek dengan rumus:

$$
A i=\frac{\sum_{j=1}^{n} K i j}{n}
$$

Keterangan:

$A i=$ rata-rata aspek ke- $i$

$K i j=$ rata-rata untuk aspek ke- $i$ untuk kriteria $\mathrm{ke}-j$

$n$ = banyaknya kriteria dalam aspek ke- $i$

Diadaptasi dari Khabibah (2006)

(4) Menghitung rata-rata total validitas:

Keterangan:

$$
V a=\frac{\sum_{i=1}^{n} A i}{n}
$$

$\mathrm{Va} \quad=$ rata-rata total validitas

$A i \quad=$ rata-rata aspek ke- $i$

$n \quad=$ banyaknya aspek

Diadaptasi dari Khabibah (2006)

(5) Menentukan kriteria validitas dengan cara mencocokkan rata-rata pada tabel 1

(6) Jika hasil yang telah dicocokkan pada tabel 1 menunjukkan kriteria kurang valid atau tidak valid, maka dilakukan revisi hingga memenuhi kriteria valid atau sangat valid.

(7)

\section{HASIL DAN PEMBAHASAN}

Penelitian ini mrnggunakan model ADDIE. Hasil pada penelitian ini akan dideskripsikan secara runtut sesuai dengan tahapan-tahapan yang dilalui selama proses penelitian.

Pada tahap Analysis dilakukan dengan analisis kebutuhan diperoleh bahwa kompetensi dasar siswa kelas IX pada materi pokok bangun ruang sisi lengkung adalah membuat generalisasi luas permukaan dan volume berbagai bangun ruang sisi lengkung (tabung, kerucut, dan bola) dan menyelesaikan masalah kontekstual yang berkaitan dengan luas permukaan dan volume bangun ruang sisi lengkung (tabung, kerucut, dan bola), serta gabungan beberapa bangun ruang sisi lengkung. Pencapaian KD dibatasi pada sub materi tabung diukur dari indikator pencapaian kompetensi yang terdiri dari lima, yaitu (1) menemukan rumus luas permukaan dan volume tabung (2) menentukan luas permukaan dan volume tabung (3) mengurutkan tabung dengan luas permukaan dan volume tabung terbesar ke terkecil (4) menyelesaikan permasalahan nyata luas permukaan dan volume tabung. Sebagian besar siswa SMPN 40 Surabaya merasa kesulitan dalam mempelajari matematika dan dari hasil wawancara dengan guru matematika, bahwa guru matematika jarang mengambil peran dalam menanamkan pentingnya melestarikan kebudayaan. Pembelajaran matematika berbasis kebudayaan jarang diterapkan sehingga pengetahuan siswa terhadap kebudayaan terbilang rendah. Akan tetapi guru matematika SMPN 40 Surabaya menambahkan bahwa sekolahnya telah menerapkan program Gerakan Literasi yang dilaksanakan setiap hari sebelum pembelajaran dimulai.

Pada tahap Design menitik beratkan pada pengembangan LKS berbasis Etnomatematika kesenian rebana untuk mendukung literasi matematis siswa yang dilengkapi dengan RPP dan tes hasil belajar (THB). LKS dirancamg untuk materi bangun ruang sisi lengkung sub materi tabung. LKS yang dikembangkan menyajikan objek etnomatematika kesenian rebana melalui materi bangun ruang sisi lengkung. Adapun perencanaan awal kerangka LKS berbasis etnomatematika yang akan dikembangkan terdiri dari (1) bagian bungkus (cover) memuat judul LKS, identitas siswa/kelompok (2) bagian isi (content worksheet) memuat KD dan tujuan pembelaran, petunjuk, informasi pendukung, materi dengan langkah kegiatan (3) bagian akhir LKS memuat alternatif jawaban. Pada tahap ini juga dirancang instrumen penilaian. Instrumen penilaian diperlukan sebagai alat ukur untuk mengetahui kualitas produk yang dikembangkan. Adapun intrumen yang di maksud yaitu instrumen untuk mengukur validitas, kepraktisan keefektifan.

(1) Instrumen validitas Instrumen yang dirancang terdiri dari empat, yaitu lembar validasi untuk LKS, RPP, THB, dan instrumen angket respon siswa. Masing-masing lembar validasi akan digunakan sebagai alat untuk mengukur validitas produk berdasarkan beberapa aspek dan kriteria.

(2) Instrumen kepraktisan

Instrumen kepraktisan yang dirancang terdiri dari tiga, yaitu lembar kepraktikan, lembar observasi guru dan siswa. Masing-masing akan digunakan sebagai alat untuk mengukur kepraktisan produk yang dikembangkan dan sebagai penilaian keterlaksanaan pembelajaran.

(3) Instrumen keefektifan

Instrumen keefektikan yang dirancang terdiri dari dua, yatu THB dan instrumen angket respon siswa. THB diperlukan untuk mengukur sejauh mana hasil belajar siswa, sedangkan angket respon siswa diperlukan untuk mengetahui respon siswa terhadap produk yang dikembangkan. Keduanya digunakan untuk mengukur keefektifan produk yang dikembangkan.

Pada tahap Development bertujuan untuk merealisasikan rancangan produk dan instrumen penelitian yang dibutuhkan. Tahap ini terdiri dari pengembangan dan penilaian produk. Keseluruhan isi LKS berorientasi pada 
etnomatematika dan literasi matematis serta disusun sesuai dengan KD dan indikator. Pada tahap Development dimulai dengan penyusunan peta kebutuhan isi LKS. Kemudian dilanjutkan dengan menentuan isi dari tiap kerangka LKS yang disusun secara sistematis supaya siswa dapat lebih mudah mempelajari materi yang disajikan melalui konteks budaya dalam kehidupan sehari-hari dan mendapat pengetahuan budaya lokal yang mengandung nilai-nilai atau penerapan konsep matematika. Produk yang sudah dikembangkan selanjutnya divalidasi oleh ahli untuk mengetahui kelayakan produk. Penilaian terhadap validitas LKS, RPP, THB, dan instrumen angket respon siswa masing-masing dilakukan oleh tiga validator.

LKS yang dikembangkan memuat beberapa kegiatan. Diawal menyajikan tentang informasi singkat mengenai kesenian rebana mulai dari sejarah, perkembangan, dan jenis-jenis alat musik. Kemudian pada kegiatan 1 menyajikan tentang definisi, unsur-unsur, luas permukaan, dan volume tabung yang harus dilengkapi oleh siswa. Selanjutnya pada kegiatan 2 menyajikan tentang kegiatan yang harus dilakukan oleh siswa berkaitan dengan aktivitas etnomatematika proses literasi matematis siswa.

Tabel 3. Keterkaitan Aktivitas Etnomatematika dan Literasi Matematis

\begin{tabular}{|c|c|c|}
\hline $\begin{array}{c}\text { Aktivitas } \\
\text { Etnomatematika }\end{array}$ & $\begin{array}{c}\text { Literasi } \\
\text { Matematis }\end{array}$ & Rincian Kegiatan \\
\hline \multirow{3}{*}{ Menjelaskan } & Merumuskan & $\begin{array}{l}\text { - Siswa berdiskusi dengan } \\
\text { kelompok masing masing } \\
\text { mengenai langkah- } \\
\text { langkah yang akan } \\
\text { dilakukan }\end{array}$ \\
\hline & Menerapkan & 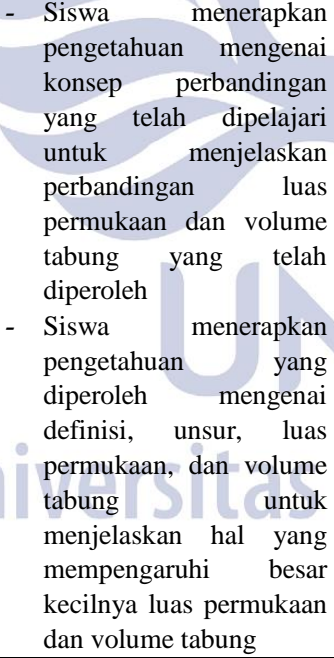 \\
\hline & Menafsirkan & $\begin{array}{lr}\text { - Siswa menafsirkan } \\
\text { perbandingan } & \text { luas } \\
\text { permukaan dan volume } & \text { vang } \\
\text { tabung yang telah } \\
\text { diperoleh } & \text { dan } \\
\text { memberikan penjelasan } \\
\text { singkat } \\
\text { - Siswa menafsirkan } \\
\text { pengaruh besar kecilnya } \\
\text { luas permukaan dan } \\
\text { volume tabung dengan } \\
\text { memberikan alasan }\end{array}$ \\
\hline
\end{tabular}

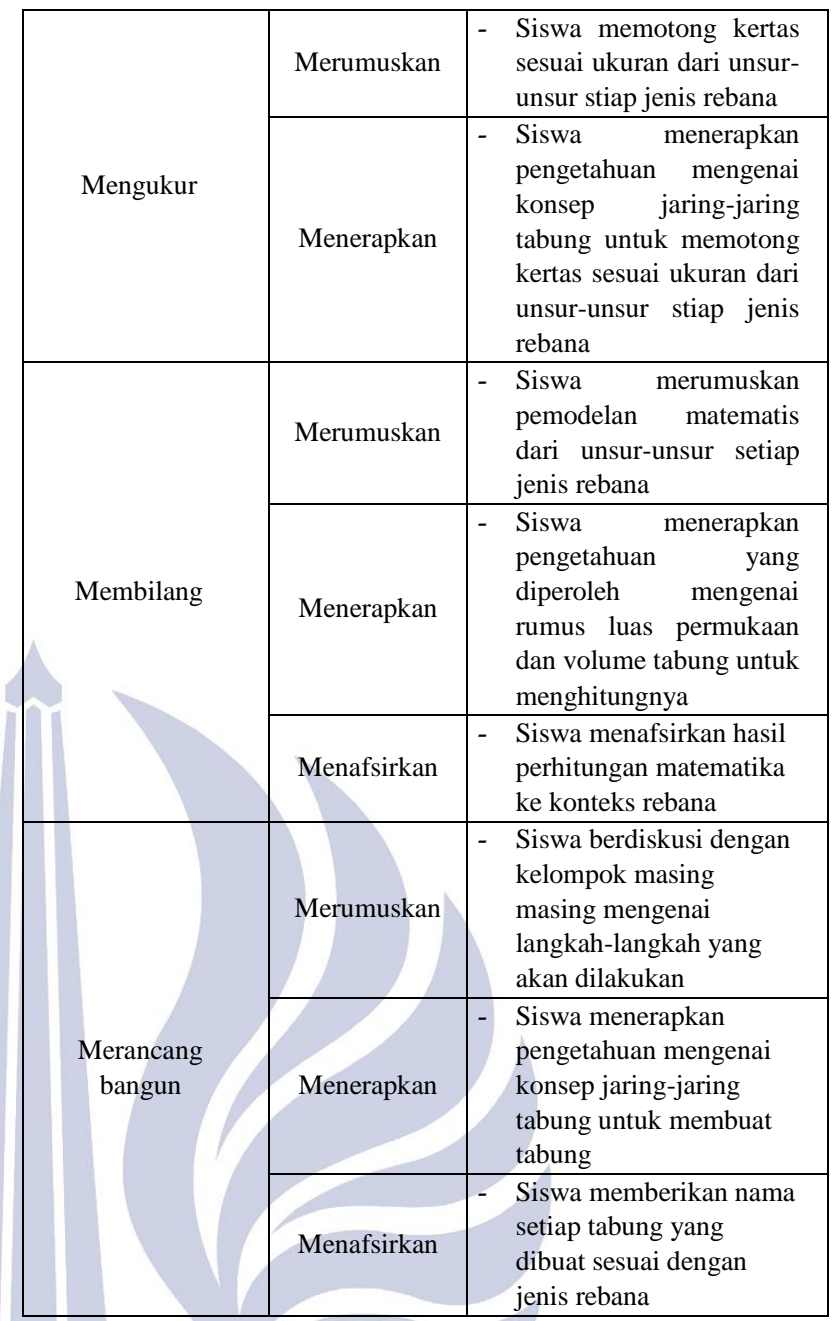

Pada tahap Implementation seharusnya dilaksanakan uji coba produk pada siswa kelas IX SMPN 40 Surabaya dengan perencanaan peneliti bertindak sebagai guru yang mengajar dan salah seorang guru matematika SMPN 40 Surabaya sebabagai observer untuk menilai keterlaksanaan pembelajaran. Tetapi karena situasi dan kondisi pada saat ini terkait wabah virus yang melanda negeri ini mengakibatkan sekolah-sekolah diliburkan dan aktivitas pembelajaran dibatasi sehingga tidak memungkinkan untuk uji coba. Sebagai gantinya pada tahap ini dilakukan uji realibitas pada beberapa siswa dengan cara peneliti berkunjung kerumah siswa satu persatu

\begin{tabular}{|c|c|c|c|}
\hline No & Korelasi & Signifikansi & $\begin{array}{c}\text { Tingkat } \\
\text { Kesukaran }\end{array}$ \\
\hline 1 & 0,610 & Signifikan & Sedang \\
\hline 2 & 0,667 & Signifikan & Mudah \\
\hline 3 & 0,594 & Signifikan & Sedang \\
\hline 4 & 0,695 & Signifikan & Sedang \\
\hline
\end{tabular}

Olah data uji reliabilitas dilakukan menggunakan software Anates. Tabel 4 memperlihatkan hasil analisis butir soal THB berupas soal uraian yang telah diuji cobakan pada siswa kelas IX di Nganjuk. Keempat soal dinyatakan signifikan.tingkat kesukaran soal dinyatakan mudah untuk nomor 2 dan sedang untuk soal nomor 1, 3, 
dan 4. Dari hasil analisis anates dengan subjek sejumlah 30 siswa, diketahui bahwa realibilitas THB berupa soal uraian adalah 0.62 dengan simpangan baku sebesar 4.69 dan rata rata sebesar 24.37 dari skor total 40. Hal ini menunjukkan bahwa THB berupa soal uraian tersebut reliabel.

Pada tahap Evaluation dilakukan dengan analisis hasil penilaian validitas produk. Tujuan pada tahap ini adalah untuk mengetahui kualitas bahan ajar yang dikembangkan berdasarkan hasil pengumpulan data yang diperoleh.

Tabel 5. Data Hasil validasi LKS

\begin{tabular}{|c|c|c|c|c|c|c|}
\hline \multirow{2}{*}{ Aspek } & \multirow{2}{*}{ Kriteria } & \multicolumn{3}{|c|}{ Validator } & \multirow{2}{*}{$K i$} & \multirow{2}{*}{$A i$} \\
\hline & & I & II & III & & \\
\hline \multirow{5}{*}{$A_{1}$} & $K_{1}$ & 4 & 3 & 4 & 3.67 & \multirow{5}{*}{3.40} \\
\hline & $K_{2}$ & 4 & 3 & 3 & 3.33 & \\
\hline & $K_{3}$ & 3 & 3 & 3 & 3.00 & \\
\hline & $K_{4}$ & 4 & 3 & 3 & 3.33 & \\
\hline & $K_{5}$ & 4 & 3 & 4 & 3.67 & \\
\hline \multirow{5}{*}{$A_{2}$} & $K_{1}$ & 3 & 4 & 3 & 3.33 & \multirow{5}{*}{3.27} \\
\hline & $K_{2}$ & 4 & 3 & 3 & 3.33 & \\
\hline & $K_{3}$ & 3 & 3 & 3 & 3.00 & \\
\hline & $K_{4}$ & 3 & 3 & 3 & 3.00 & \\
\hline & $K_{5}$ & 4 & 4 & 3 & 3.67 & \\
\hline \multirow{5}{*}{$A_{3}$} & $K_{1}$ & 4 & 3 & 3 & 3.33 & \multirow{5}{*}{3.26} \\
\hline & $K_{2}$ & 3 & 3 & 3 & 3.00 & \\
\hline & $K_{3}$ & 4 & 3 & 3 & 3.33 & \\
\hline & $K_{4}$ & 4 & 3 & 3 & 3.33 & \\
\hline & $K_{5}$ & 4 & 3 & 3 & 3.33 & \\
\hline \multirow{5}{*}{$A_{4}$} & $K_{1}$ & 3 & 3 & 3 & 3.00 & \multirow{5}{*}{3.07} \\
\hline & $K_{2}$ & 3 & 3 & 3 & 3.00 & \\
\hline & $K_{3}$ & 4 & 3 & 3 & 3.33 & \\
\hline & $K_{4}$ & 3 & 3 & 3 & 3.00 & \\
\hline & $K_{5}$ & 3 & 3 & 3 & 3.00 & \\
\hline
\end{tabular}

Hasil penilaian menunjukkan validator I dan II menyimpulkan bahwa LKS layak digunakan dengan revisi (LDR) dengan perolehan validitas 3,25 dan 3,55. Sedangkan validator III menyimpulkan bahwa LKS layak digunakan (LD) dengan perolehan validitas 3,10. Sehingga kualitas validitas LKS berada pada kriteria valid dengan perolehan rata-rata total validitas 3,25. Selain itu validator memberikan beberapa masukan. Pertama, Akan lebih baik jika betul-betul dikaitkan dengan bentuk rebana sesungguhnya, bukan dibawa ke tabung semua. Bisa dikaitkan dengan bahan yang digunakan untuk membuat alat-alat tersebut. Kedua, Pertanyaan pada kegiatan di LKS lebih baik difokuskan dahulu ke mengurutkan volume baru luas permukaan. Ketiga, saat terjun dilapangan dan berhadapan dengan siswa maka guru pengajar mohon mendampingi secara intens karena etnomatematika ini merupakan penelitian yang jarang diteliti sebelumnya.

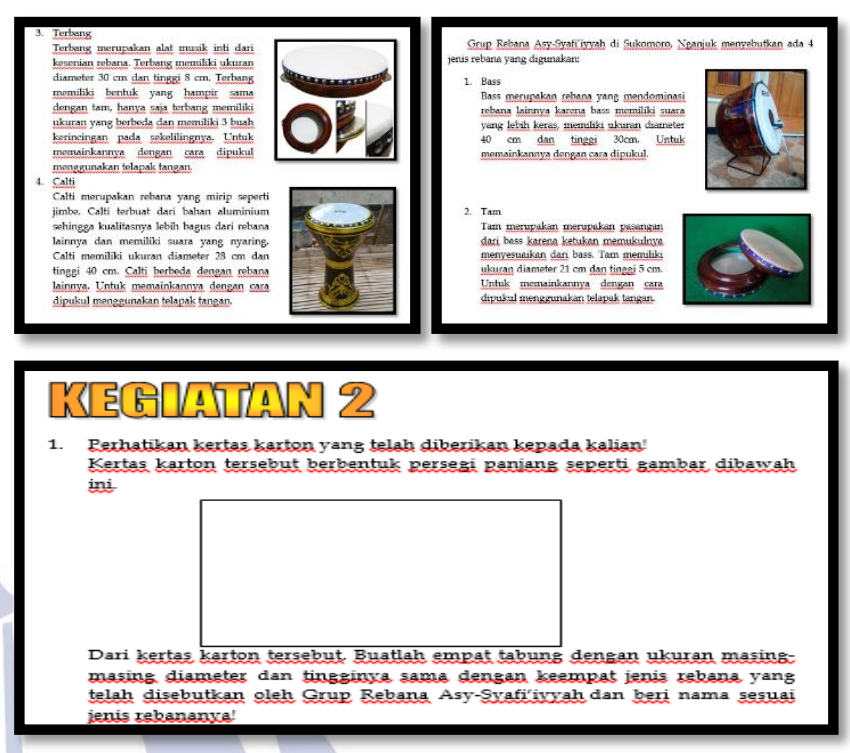

Gambar 1. Fakta Etnomatematika

Gambar 1 merupakan bagian dari LKS yang memuat fakta etnomatematika yang disusun dan disetujui validator. Dari fakta tersebut, siswa diarahkan untuk mengerjakan kegiatan 2 secara berkelompok.

Tabel 6. Data Hasil Validasi RPP

\begin{tabular}{|c|c|c|c|c|c|c|}
\hline \multirow{2}{*}{ Aspek } & \multirow{2}{*}{ Kriteria } & \multicolumn{3}{|c|}{ Validator } & \multirow{2}{*}{$K i$} & \multirow{2}{*}{$A i$} \\
\hline & & I & II & III & & \\
\hline$A_{1}$ & $K_{1}$ & 4 & 3 & 4 & 3.67 & 3.67 \\
\hline \multirow{2}{*}{$A_{2}$} & $K_{1}$ & 3 & 3 & 3 & 3.00 & \multirow{2}{*}{3.33} \\
\hline & $K_{2}$ & 4 & 4 & 3 & 3.67 & \\
\hline \multirow{2}{*}{$A_{3}$} & $K_{1}$ & 4 & 4 & 3 & 3.67 & \multirow{2}{*}{3.50} \\
\hline & $K_{2}$ & 4 & 3 & 3 & 3.33 & \\
\hline$A_{4}$ & $K_{1}$ & 4 & 3 & 3 & 3.33 & 3.33 \\
\hline \multirow{3}{*}{$A_{5}$} & $K_{1}$ & 4 & 4 & 3 & 3.67 & \multirow{3}{*}{3.33} \\
\hline & $K_{2}$ & 4 & 3 & 3 & 3.33 & \\
\hline & $K_{3}$ & 3 & 3 & 3 & 3.00 & \\
\hline
\end{tabular}

Hasil penilaian validator I dan II menyimpulkan bahwa RPP layak digunakan dengan revisi (LDR) dengan perolehan validitas 3,77 dan 3,33, sedangkan Validator III menyimpulkan bahwa RPP layak digunakan (LD) dengan perolehan validitas 3,11 . Sehingga validitas RPP berada pada kriteria valid dengan rata-rata total validitas 3,43. Selain itu validator juga memberikan beberapa masukan. Pertama, Model pembelajaran yang digunakan adalah kooperatif, sebaiknya ada teknik untuk menilai hasil kerja kelompoknya.. Kedua, Motivasi baiknya dihubungkan dengan unsur etnomatematika yang diusung. Begitu juga dengan kegiatan mengamati.

Kegiatan etnomatematika yang disajikan dalam RPP termuat dalam kegiatan selama pembelajaran. Pada kegiatan awal, guru memberikan motivasi kepada siswa dengan menayangkan video tentang kesenian rebana dan meminta siswa untuk mengidentifikasi bentuk dari jenisjenis alat musik pada kesenian rebana. Pada kegiatan inti, guru menyajikan informasi mengenai definisi, unsur, luas permukaan, dan volume tabung serta mengaitkannya dengan alat musik pada kesenian rebana. Kemudian guru 
meminta siswa untuk menanggapi informasi yang disajikan. Selanjutnya guru meminta siswa untuk mengerjakan LKS yang juga terdapat kegiatan etnomatematika di dalamnya. Pada kegiatan penutup, guru memandu siswa untuk membuat kesimpulan bahwa dalam mempelajari konsep matematika khususnya pada bab bangun ruang sisi lengkung materi tabung melalui budaya yang kita miliki dengan menerapkan pembelajaran etnomatematika.

Tabel 7. Data Hasil Validasi THB

\begin{tabular}{|c|c|c|c|c|c|c|}
\hline \multirow{2}{*}{ Aspek } & \multirow{2}{*}{ Kriteria } & \multicolumn{3}{|c|}{ Validator } & \multirow{2}{*}{$K i$} & \multirow{2}{*}{$A i$} \\
\hline & & I & II & III & & \\
\hline \multirow{3}{*}{$A_{1}$} & $K_{1}$ & 4 & 4 & 3 & 3.67 & \multirow{3}{*}{2.78} \\
\hline & $K_{2}$ & 1 & 2 & 3 & 2.00 & \\
\hline & $K_{3}$ & 2 & 3 & 3 & 2.67 & \\
\hline \multirow{3}{*}{$A_{2}$} & $K_{1}$ & 4 & 4 & 3 & 3.67 & \multirow{3}{*}{3.67} \\
\hline & $K_{2}$ & 4 & 4 & 3 & 3.67 & \\
\hline & $K_{3}$ & 4 & 4 & 3 & 3.67 & \\
\hline \multirow{2}{*}{$A_{3}$} & $K_{1}$ & 4 & 4 & 3 & 3.67 & \multirow{2}{*}{3.50} \\
\hline & $K_{2}$ & 4 & 3 & 3 & 3.33 & \\
\hline
\end{tabular}

Hasil penilaian validator I, II dan III menyimpulkan bahwa THB layak digunakan dengan revisi (LDR) dengan perolehan validitas $3,37,3,50$, dan 3,00. Sehingga validitas THB berada pada kriteria valid dengan rata-rata total validitas 3,32. Selain itu validator juga memberikan beberapa masukan. Pertama, soal tidak ada kaitannya sama sekali dengan etnomatematika kesenian rebana, sebaiknya dikaitkan sehingga valid digunakan untuk mengukur keberhasilan hasil belajar matematika melalui perangkat pembelajaran yang disusun. Kedua, mungkin perlu ditambahkan nama orang dan aktifitas dari soal di atas agar soal terlihat lebih kontekstual. Misalnya "Pak Aris memiliki tangki berbentuk tabung berisi 770 liter air akan digunakan untuk persediaan air kolam. Jari-jari tangki pak Aris memiliki ukuran $70 \mathrm{~cm}$ dengan $\pi=\frac{22}{7}$ Pak Aris ingin membuat tangki lagi dengan ukuran yang sama. Berapa Luas permukaan tangki agar pak Aris dapat membuat tangki kolam lagi?"

Tabel 8. Data Hasil Validasi Instrumen Angket Respon Siswa

\begin{tabular}{|c|c|c|c|c|c|c|}
\hline \multirow{2}{*}{ Aspek } & \multirow{2}{*}{ Kriteria } & \multicolumn{3}{|c|}{ Validator } & \multirow{2}{*}{$\boldsymbol{K} \boldsymbol{*}$} & \multirow{2}{*}{$\boldsymbol{A} \boldsymbol{i}$} \\
\cline { 2 - 6 } & & I & II & III & & \\
\hline \multirow{2}{*}{$A_{1}$} & $K_{1}$ & 4 & 3 & 3 & 3.33 & \multirow{2}{*}{3.33} \\
\cline { 2 - 6 } & $K_{2}$ & 4 & 3 & 3 & 3.33 & \\
\hline \multirow{3}{*}{$A_{2}$} & $K_{1}$ & 4 & 4 & 3 & 3.67 & \multirow{2}{*}{3.67} \\
\cline { 2 - 6 } & $K_{2}$ & 4 & 4 & 3 & 3.67 & \\
\cline { 2 - 6 } & $K_{3}$ & 4 & 4 & 3 & 3.67 & \\
\hline
\end{tabular}

Hasil penilaian validator I, II dan III menyimpulkan bahwa angket respon siswa layak digunakan (LD) dengan perolehan validitas4,00,3,60,3,00. Sehingga validitas instrument angket respon siswa berada pada kriteria valid dengan rata-rata total validitas 3,57 . Selain itu validator juga memberikan beberapa masukan. Pertama, perlu ditambahkan butir yang mengukur respon siswa terhadap kemudahan belajar dan kemudahan memahami materi dengan menggunakan bahan ajar yang dikembangkan. Kedua, mungkin perlu diberi tambahan kolom keterangan atau alasan untuk memperjelas pernyataan.

Berdasarkan hasil yang telah dipaparkan di atas, proses perancangan bahan ajar berbentuk LKS berbasis Etnomatematika kesenian rebana yang dilengkapi dengan RPP, THB, dan instrumen angket respon siswa sesuai dengan Shirley dalam Marsigit (2016) bahwa walaupun terbilang relatif baru dalam dunia kependidikan, kebudayaan yang tumbuh dan berkembang dalam kehidupan masyarakat dapat digunakan sebagai pusat proses, pembelajaran dan metode pengajaran matematika. Dari kelima tahapan ADDIE, pada penelitian ini dibatasi menjadi 4 tahapan tanpa melaksanakan tahap keempat yaitu implementation karena situasi dan kondisi pada saat ini terkait wabah virus yang melanda negeri ini mengakibatkan sekolah-sekolah diliburkan mengakibatkan aktivitas pembelajaran dibatasi dan tidak memungkinkan untuk uji coba, sehingga tujuan dari penelitian ini untuk menghasilkan produk yang siap diuji cobakan..

Integrasi etnomatematika kesenian rebana dalam LKS pada materi bangun ruang sisi lengkung menyajikan informasi tentang sejarah, kegunaaan, dan jenis-jenis pada kesenian rebana yang membuat pembelajaran akan lebih bermakna, karena selain belajar konsep dalam waktu yang sama siswa juga mempelajari kearifan lokal. Diharapkan siswa mampu lebih menghargai, dan menyadari pentingnya nilai budaya dalam menjalankan aktivitas dalam kehidupan sehari-hari.

Penilaian pada LKS, RPP, THB, dan instrumen angket respon siswa masing-masing memperoleh rata-rata total validitas $3 \leq V a<4$ sehingga berdasarkan kriteria Khabibah (2006) dinyatakan valid. Selain itu penilaian umum dinyatakan oleh validator bahwa RPP, LKS, dan THB dapat digunakan dengan revisi sesuai kritik dan saran. Kemudian direvisi oleh peneliti supaya RPP, LKS, dan THB dapat digunakan tanpa revisi. Hasil tersebut sesuai dengan hasil penelitian Nelawati dkk, (2018) yang menunjukkan pengembangan bahan ajar berbasis etnomatematika dapat dinyatakan valid. Bahan ajar yang dikembangkan juga dapat digunakan sebagai salah satu alternatif untuk mengatasi kesulitan siswa dalam memahami materi (Siti M dkk, 2018; Ayuningtyas dan Setiana, 2019)

Produk yang dikembangkan tidak hanya menerapkan etnomatematika saja ke dalam pembelajaran, tetapi juga dikaitkan dengan literasi matematis. Objek yang digunakan juga seringkali dijumpai siswa dalam kehidupan sehari- 
hari, sehingga siswa lebih mudah memahaminya. Berbeda dengan penelitian Ayuningtyas dan Setiana (2019) yang mengembangkan bahan ajar berbasis etnomatematika tanpa mengaitkannya dengan literasi matematis dan menggunakan objek etnomatematika Kraton Yogyakarta, sehingga tidak semua siswa dapat menjumpainya dalam kehidupan sehari-hari.

\section{PENUTUP}

\section{Simpulan}

Penelitian ini terbatas pada pengembangan bahan ajar berbasis etnomatematika kesenian rebana untuk mendukung literasi matematis siswa SMP berupa LKS yang dilengkapi dengan RPP, THB, dan instrumen angket respon siswa. Pada pengembangannya, penyajian materi pembelajaran dilakukan dengan menampilkan obyek Etnomatematika kesenian rebana.

(1) Hasil wawancara dengan guru matematika menunjukkan bahwa menunjukkan bahwa guru jarang mengambil peran dalam menanamkan pentingnya melestarikan kebudayaan karena pembelajaran matematika berbasis kebudayaan jarang diterapkan sehingga pengetahuan siswa terhadap kebudayaan terbilang rendah.

(2) LKS telah mencapai kriteria valid dengan perolehan rata-rata total validitas sebesar 3,25 dan layak untuk diuji cobakan. Tetapi LKS belum bisa dikatakan praktis dan efektif karena tahap implementation tidak bisa dilakukan.

(3) RPP telah mencapai kriteria valid dengan perolehan rata-rata total validitas sebesar 3,43 dan layak untuk diuji cobakan. Tetapi RPP belum bisa dikatakan praktis dan efektif karena tahap implementation tidak bisa dilakukan.

(4) THB telah mencapai kriteria valid dan reliabel dengan perolehan rata-rata total validitas sebesar 3,32 dan reabilitas 0,62 sehingga layak digunakan untuk mengukur keefektifan bahan ajar yang dikembangkan.

(5) Instrumen angket respon siswa telah mencapai kriteria valid dengan perolehan rata-rata total validitas sebesar 3,57 dan layak digunakan untuk mengukur keefektifan bahan ajar yang dikembangkan.

\section{Saran}

Bagi para pembaca yang tertarik mengembangkan bahan ajar serupa dapat mengembangkan bahan ajar berbasis etnomatematika yang lebih luas dan lebih lengkap lagi. Tentunya dalam pengembangan tersebut, dapat menggunakan objek etnomatematika yang lebih sesuai dengan materi yang dipelajari dan sering dijumpai oleh siswa. Hal ini bertujuan untuk mengenalkan budaya daerah kepada siswa dalam upaya melestarikan kebudayaan sekaligus untuk mendukung literasi matematis siswa.

\section{DAFTAR PUSTAKA}

Abdussakir. 2018. "Literasi Matematis dan Upaya Pengembangannya dalam Pembelajaran di Kelas". Seminar Pendidikan Matematika STKIP PGRI Sumenep.

Ayuningtyas, Annis D \& Setiana Dafid S. 2019. Pengembangan Bahan Ajar Matematika Berbasis Etnomatematika KratonYogyakarta. Jurnal Program Studi Pendidikan Matematika. Vol. 8 (1): hal 11-19

Budiarto, Mega T. 2016. Etno-Matematika: Sebagai Batu Pijakan untuk Pembelajaran Matematika. Makalah disajikan dalam Prosiding Seminar Nasional Pendidikan Matematika 2016, Surabaya.

Budiarto, Mega T. 2019. Ethnomathematics: Formal Mathematics Milestones for Primary Education. Journal of Physics: Conference Science. Hal 1-7

D'Ambrosio, U. 1985. Ethnomathematics and its Place in The History and Pedagogy of Mathematics. For the Learning of Mathematics. Vol.5 (1):hal. 44-48.

Ditasona, C. 2018. Ethnomathematics Exploration of the Toba Community:Elements of Geometry Transformation Contained in Gorga (Ornamen on Bataks House). IOP Conf. Series: Materials Science and Engineering. Vol 1 (335):hal. 1-7.

Fajriyah, Euis. 2018. Peran Etnomatematika Terkait Konsep Matematika dalam Mendukung Literasi. PRISMA 1, 2018. Jurnal Prisma, Prosiding Seminar Nasional Matematika. Program Pascasarjana, Universitas Negeri Semarang, Semarang.

Francois, K. 2012. Ethnomathematics in a European Context: Towards an Enrishedmeaning of Etnomathematics. Journal of Mathematics and Culture ,191-208.

Jarnawi A. D \& Revina P. (2018). Pengembangan Bahan Ajar Berbasis Etnomatematika Dalam Pembelajaran Matematika Sekolah Menengah Pertama. JNPM (Jurnal Nasional Pendidikan Matematika). Vol.2 No. 1 Hal. $133-150$

Khabibah, Siti. 2006. Pengembangan Model Pembelajaran Matematika dengan Soal Terbuka Untuk Meningkatkan Kreativitas Siswa Sekolah Dasar. Disertasi tidak diterbitkan. Surabaya: Pascasarjana Unesa.

Koentjaraningrat. 1985. Pengantar Ilmu Antropologi. Jakarta: Aksara Baru

Kusumah, Yaya S. 2011. "Literasi Matematis". Makalah disampaikan dalam seminar nasional Jurusan PMIPA FKIP Universitas Lampung Pada Tanggal 26 November2011. Proseding ISBN 978-979-8150-32-8.

Majid, Abdul. 2011. Perencanaan Pembelajaran Pengembangan Standar Kompetensi Guru. Bandung: PT Remaja Rosdakarya.

Marsigit. 2016. Pembelajaran Matematika dalam Perspektif Kekinian. Math Didactic: Jurnal Pendidikan Matematika 2(3); 132-141. 
Muhtadi, Dedi., dkk. 2017. Sundanese Ethnomathematics: Mathematical Activities in Estimating, Measuring, and Making Patterns. Journal on Mathematics Education. Vol.8 (2): hal 185-198.

Nelawati, dkk. 2018. Pengembangan Bahan Ajar Bercirikan Etnomatematika Suku Komering Materi Bangun Datar Siswa Sekolah Dasar. Makalah disajikan dalam Prosiding Seminar Nasional Matematika dan Pendidikan Matematika 2018, Lampung.

OECD. 2017. PISA 2015 Assessment and Analytical Framework: Science, Reading, Mathematic, FinancialLiteracy and Collaborative Problem Solving, revised edition.PISA. Paris: OECD Publishing.

Ojose, B. 2011. "Mathematics Literacy: Are We Able to Put the Mathematics We Learn into every Day Use?". Journal of Mathematics Education. 4, 89-100.

Pannen, P. 2010. Pendidikan Sebagai Sistem. Jakarta: Depdiknas.

Prastowo, Andi. 2013. Panduan Kreatif Membuat Bahan Ajar Inovatif. Jogjakarta: Diva Press.

Prayitno, I. W. 2016. Pengaruh Pembelajaran Etnomatematika Sunda terhadap Kemampuan Literasi Matematis Siswa Sekolah Dasar. (Skripsi). Universitas Pendidikan Indonesia. Bandung.

Putri, L. I. 2017. Eksplorasi Etnomatematika Kesenian Rebana Sebagai Sumber Belajar Matematika Pada Jenjang MI. Jurnal Ilmiah "PENDIDIKAN DASAR" Vol. IV, (1).

Rachmawati, I. 2012. Eksplorasi Etnomatematika Masyarakat Sidoarjo, E-Jurnal UNESA. Vol 1 No 1.

CT Pada Implementasi Kurikulum 2013, 123-131
Risdiyanti, I \& Prahmana, R. C. I.. 2017. Ethnomathematics: Exploration in Javanese Culture. Journal of Physics: Conference Science. Hal. 1-7.

Sarinah. 2016. Ilmu Sosial Budaya Dasar (Di perguruan Tinggi). Yogyakarta: Deepublish.

Steen, et al. 2007. "Developing Mathematical Literacy". Dalam Blum, W. et al. (Eds), Modeling and Aplication in Mathematics Education: The 14th ICMI Study. pp 285-294.

Sani, R. A. 2013. Inovasi Pembelajaran. Jakarta: Bumi Aksara.

Siti M, Rani W, \& Achi R. (2018). Pengembangan Modul Pembelajaran Matematika Berbasis Etnomatematika Menggunakan Metode Inkuiri. Desimal : Jurnal matematika. Vol. 1 No. 2 hal. 119 - 126

Sugiyono. (2017). Metode Penelitian dan Pengembangan (Research and Development $r \& d$ ). Bandung: Alfabeta.

Sumantri, M. S. 2015. Strategi Pembelajaran. Jakarta: Rajawali Pers.

Tohir, Mohammad. 2019. Hasil PISA Indonesia Tahun 2018 Turun Dibanding Tahun 2015, (Online), (https://matematohir.wordpress.com/2019/12/03/hasilpisa-indonesia-tahun-2018-turun-dibanding-tahun2015/, diakses 21 April 2020)

Wahyuni, A dkk. 2013. Peran Etnomatematika Dalam Membangun Karakter Bangsa. Makalah disajikan dalam Prosiding Seminar Nasional Matematika dan Pendidikan Matematika 2013, Yogyakarta.

Wiyono, K. 2013. Pengembangan Model Pembelajaran Fisika Berbasis I

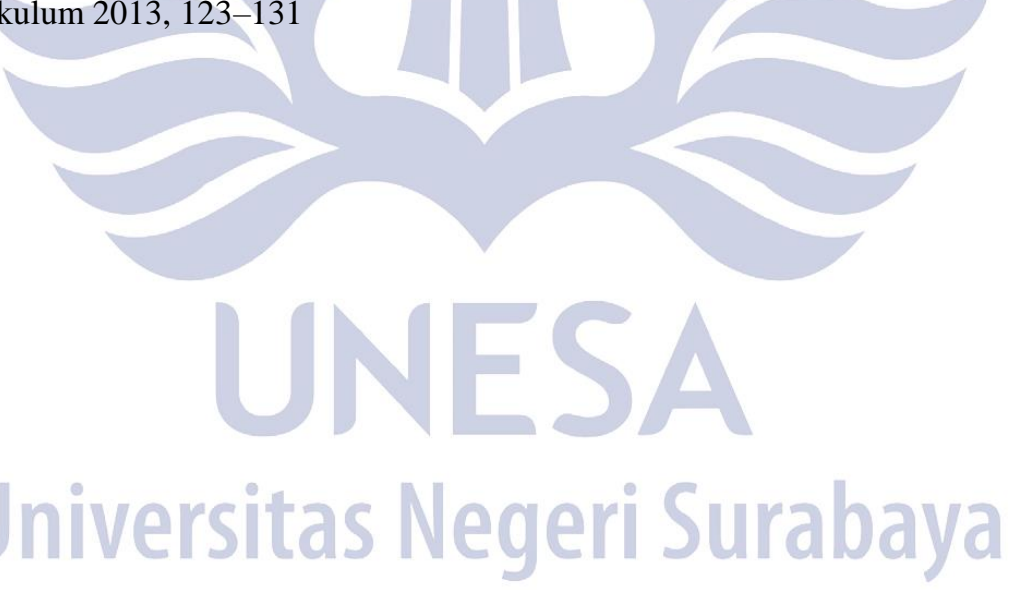

